\title{
EVALUASI PENYUSUNAN ANGGARAN PADA PEMERINTAH DESA KAUNERAN KECAMATAN SONDER KABUPATEN MINAHASA
}

\author{
Tirsa Alicia Menajang ${ }^{1}$, David P.E Saerang ${ }^{2}$, Treesje Runtu ${ }^{3}$ \\ ${ }^{1,2,3}$ Fakultas Ekonomi dan Bisnis, Jurusan Akuntansi, Universitas Sam Ratulangi, Jl.Kampus Bahu, Manado, \\ 95115, Indonesia \\ E-mail : tirsa.men@gmail.com
}

\begin{abstract}
Budget is an important part in achieving the objectives and planning activities that will be implemented in the government. The existence of budgeting on a village can be a guideline for the village government in the planning of the development activity program for the year. Budget drafting in the Kauneran village Sonder district of Minahasa regency discussed with the government, community and related parties, so that the formation of activities program aims for development and welfare of village communities. In the process of budget drafting, evaluation is needed as accountability of the village finances so that the budget becomes very important. This study aims to evaluate the process of budget preparation at the government of Kauneran village Sonder district of Minahasa regency. The data analysis used is descriptive analysis with qualitative approach. The results of the research shows that process of preparing the budget of Kauneran Village Government Minahasa regency is accordance with government regulations in force.
\end{abstract}

Keywords: Budget drafting, Evaluation

\section{PENDAHULUAN}

Kewenangan bagi daerah otonom dalam hal untuk mengatur dan mengurus setiap kepentingan diperuntukkan bagi masyarakat setempat berdasarkan aspirasi masyarakat sebagai katan Negara Kesatuan Republik Indonesia menurut UU No. 9 Tahun 2015. Dengan otonomi daerah tersebut, pemerintah daerah memiliki kebebasan untuk membuat inisiatif sendiri, mengelola dan mengoptimalkan sumber daya daerah. Diadakannya kebebasan untuk berinisiatif menjadi suatu dasar pemberian otonomi daerah, karena dasar pemberian otonomi daerah adalah dapat berbuat sesuai dengan kebutuhan daerah setempat. Dalam rangka pertanggungjawaban pemerintah daerah harus melakukan optimalisasi, efisiensi dan efektivitas dalam merencanakan program-program untuk kesejahteraan masyarakat. Daerah otonom juga diberikan sumber-sumber dana atau penerimaan yang akan digunakan untuk memenuhi kebutuhan biaya pelaksanaan tugas-tugas pelayanan kepada masyarakat dalam hal pembangunan daerah serta adanya pengawasan untuk anggaran tersebut agar dapat dikelola dan dipertanggungjawabkan dengan baik karena implementasi otonomi bagi desa adalah pelopor sistem demokrasi yang otonom dan berdaulat penuh. Sejak lama, desa telah memiliki sistem dan mekanisme pemerintahan serta norma sosial masing-masing Aida (2013).

Penyelenggaraan kewenangan desa yang ditugaskan oleh pemerintah didanai oleh APBN (Anggaran Pendapatan dan Belanja Negara) dan dialokasikan pada bagian anggaran Kementerian/Lembaga dan disalurkan melalui satuan kerja perangkat daerah Kabupaten/Kota sehingga penyelenggaraan kewenangan Desa yang ditugaskan oleh pemerintah daerah didanai oleh APBD (Anggaran Pendapatan dan Belanja Daerah). Dalam melaksanakan kewenangannya tersebut, pemerintah desa memiliki sumber-sumber pendapatan daerah untuk membiayai semua kegiatan yang berhubungan dengan kepentingan yang ada di desa. Penyelenggaraan kewenangan desa berdasarkan hak asal usul dan kewenangan lokal berskala desa didanai oleh APBDes (Anggaran Pendapatan dan Belanja Desa). Pengelolaan keuangan 
desa merupakan bagian dari keseluruhan kegiatan yang meliputi perencanaan, pelaksanaan, penatausahaan, pelaporan, dan pertanggungjawaban keuangan desa sehingga penyusunan anggaran menjadi sangat penting dikarenakan jika anggaran yang tidak efektif dan tidak berorientasi pada kinerja sehingga akan dapat menggagalkan program perencanaan yang telah disusun. Kebutuhan pembangunan desa merupakan suatu prioritas pemerintah dan masyarakat yang telah disepakati dalam musyawarah desa dan sesuai dengan prioritas pada Pemerintah Daerah Kabupaten/Kota, Pemerintah Daerah Provinsi, dan Pemerintah.

Berdasarkan Peraturan Pemerintah Nomor 47 Tahun 2015, Perencanaan pembangunan desa harus disusun dan diselenggarakan berdasarkan hasil kesepakatan dalam musyawarah desa. Musyawarah desa dalam rangka penyusunan RKP (Rencana Kerja Pemerintah) Desa dilaksanakan paling lambat pada bulan Juni tahun anggaran berjalan (pasal 114). Perencanaan pembangunan desa menjadi pedoman bagi Pemerintah Desa dalam menyusun rancangan RPJM (Rencana Pembangunan Jangka Menengah) Desa, RKP Desa, dan daftar usulan RKP Desa (pasal 115). Dalam menyusun Rencana Pembangunan Jangka Menegah Desa dan Rencana Kerja Pemerintah Desa, Pemerintah Desa wajib menyelenggarakan musyawarah perencanaan pembangunan desa secara partisipatif. Musyawarah perencanaan pembangunan Desa diikuti oleh Badan Permusyawaratan Desa dan unsur masyarakat Desa.

Kebutuhan pembangunan meliputi, tetapi tidak terbatas pada kebutuhan primer, pelayanan dasar, lingkungan, dan kegiatan pemberdayaan masyarakat desa. Anggaran Pendapatan dan Belanja Daerah (APBD) adalah Rancangan Keuangan Pemerintah Daerah yang dibahas dan setujui bersama oleh Pemerintah Daerah dan DPRD yang telah ditetapkan dengan Peraturan Daerah, merupakan hak dan kewajiban yang diberikan kepada Kepala Daerah untuk mengelola keuangan daerah sehingga dialokasi pada desa atau sering disebut ADD (Alokasi Dana Desa). Penyusunan APBDes didasarkan pada Permendagri No. 113 tahun 2014. APBDes merupakan bagian dari tahapan perencanaan dalam keuangan desa, dalam pengelolaan APBDes didasarkan pada prinsip partisipasi, transparansi dan akuntabel. Pada penyusunan anggaran pemerintah desa dapat belajar lebih mandiri dalam mengelola wilayahnya, sehingga APBDes juga dapat menjadi sarana masyarakat desa untuk menyalurkan aspirasinya juga berpartisipasi dalam pembangunan desa melalui pengelolaan keuangannya untuk kesejahteraa bersama.

\section{TINJAUAN PUSTAKA}

\subsection{Akuntansi}

Akuntansi adalah suatu disiplin ilmu yang terus berkembang sejalan dengan makin meningkatnya kebutuhan informasi keuangan. Perkembangan tersebut telah menempatkan akuntansi menjadi bagian yang tidak terpisahkan dari roda pemerintahan dan dunia usaha, Harahap (2015:4). Akuntansi merupakan proses pengidentifikasian, pengukuran, pencatatan, penggolongan dan pengikhtisaran serta pelaporan informasi keuangan dalam ukuran moneter (uang) dalam suatu perusahan atau organisasi yang ditujukan kepada pihak-pihak yang berkepentingan yang terkait dalam hal pengambilan keputusan sehingga menyatakan akuntansi sebagai seni pencatatan, penggolongan, peringkasan, dan pelaporan transaksitransaksi keuangan suatu organisasi dengan cara-cara tertentu yang sistematis, serta penafsiran terhadap hasilnya. Effendi (2015:1)

Secara umum dapat disimpulkan akuntansi adalah suatu aktifitas penyedia informasi keuangan dan informasi tersebut digunakan untuk menilai posisi dan pola kerja perusahaan, organisasi atau sistem pemerintahan sehingga dapat memprediksikan pertimbanganpertimbangan untuk mengerjakan keputusan yang tepat. 


\subsection{Akuntansi Sektor Publik}

Akuntansi sektor publik adalah aktivitas jasa yang terdiri dari mencatat, mengklasifikasikan dan melaporkan kejadian atau transaksi ekonomi yang akhirnya akan menghasilkan suatu informasi keuangan yang akan dibutuhkan oleh pihak-pihak tertentu untuk pengambilan keputusan yang diterapkan pada pengelolaan dana publik di lembagalembaga tinggi negara dan departemendepartemen dibawahnya. Wiratna (2015:1)

\subsection{Tujuan Akuntansi Sektor Publik}

Halim (2014: 4) Tujuan akuntansi pemerintahan dan akuntansi bisnis pada umumnya adalah sama yaitu :

1. Akuntabilitas

Di dalam pemerintahan, keuangan Negara yang dikelola harus dapat dipertanggungjawabkan sesuai dengan peraturan amanat konstitusi.

2. Manajerial

Akuntansi pemerintahan memungkinkan pemerintah untuk melakukan suatu perencanaan terkait dengan penyusunan APBN dan strategi pembangunan lainnya, untuk melakukan pelaksanaan kegiatan pembangunan dan pengendalian atas kegiatan tersebut dalam rangka pencapaian ketaatan kepada peraturan perundang-undangan, efisiensi, efektivitas, dan ekonomis.

3. Pengawasan

Pemeriksaan keuangan di Indonesia terdiri dari pemeriksaan keuangan secara umum, pemeriksaan ketaatan, dan pemeriksaan operasional atau manajerial.

\subsection{Anggaran}

Anggaran adalah suatu proses yang dilakukan untuk perencanaan kebutuhankebutuhan yang tidak terbatas. Anthony dan Govindarajan (2013) mengemukakan bahwa anggaran merupakan alat penting untuk perencanaan dan pengendalian jangka pendek yang efektif dalam organisasi. Anggaran memiliki dua peran penting di dalam sebuah organisasi, yaitu pertama berperan sebagai alat perencanaan dan kedua berperan sebagai alat pengendalian.

\subsection{Karakteristik Anggaran}

Menurut Indra Bastian (2014:191), karakteristik anggaran publik terdiri dari:

1. Anggaran yang dinyatakan dalam satuan keuangan dan satuan nonkeuangan;

2. Anggaran pada umumnya mencakup jangka waktu tertentu yang telah ditetapkan, terkait satu atau beberapa tahun;

3. Anggaran yang didalamya berisi komitmen atau kesanggupan pada manajemen dalam rangka untuk mencapai sasaran yang ditetapkan;

4. Usulan pada anggaran yang ditelaah juga yang telah disetujui oleh pihak yang berwenang harus lebih tinggi dari penyusun anggaran;

5. Anggaran yang telah disusun hanya dapat diubah dalam suatu kondisi tertentu.

\subsection{Tujuan dan Manfaat Anggaran}

Tujuan penyusunan anggaran menurut Sasongko dan Parulian (2013: 3) :

1. Perencanaan

Anggaran dapat memberikan arahan dalam penyusunan anggaran dengan tujuan dan kebijakan perusahaan.

2. Koordinasi

Anggaran merupakan hal yang dapat mempermudah dalam koordinasi antar bagianbagian di dalam perusahaan.

3. Motivasi

Anggaran membuat manajemen dapat menetapkan setiap target-target tertentu yang harus dicapai dalam perusahaan.

4. Pengendalian 
Adanya anggaran dalam suatu perusahaan juga dapat memungkinkan bagi manajemen agar dapat melakukan tugas dan fungsi dalam pengendalian dari setiap aktivitas-aktivitas yang dilaksanakan dalam perusahaan tersebut.

\section{METODE PENELITIAN}

\subsection{Jenis Penelitian}

Pada penelitian ini, peneliti mengunakan jenis penelitian kualitatif. Pengertian menurut Creswell (2012: 3) penelitian kualitatif merupakan metode-metode untuk mengeksplorasi dan memahami makna yang oleh sejumlah individu atau sekelompok orang yang dianggap berasal dari masalah sosial atau kemanusiaan.

\subsection{Jenis dan Sumber Data}

Jenis data dalam penelitian ini adalah data kualitatif yang merupakan kumpulan data yang bersifat deskriptif menyangkut tanggapan langsung responden. Sumber dalam penelitian ini berupa catatan hasil wawancara yang diperoleh melalui pada pihak pemerintah terkait dalam penelitian sehingga peneliti mendapatkan informasi sesuai data yang akan diteliti. Selain itu, penulis juga melakukan observasi lapangan dan mengumpulkan data dalam bentuk catatan tentang situasi dan kejadian yang ada

\subsection{Metode Analisis Data}

Metode yang digunakan untuk menganalisa data adalah metode deskriptif yang dimulai dengan mengumpulkan data dan diuraikan agar dapat diperoleh gambaran yang jelas dan menganalisis proses penyusunan anggaran RPJMDes, RKPDes pada pemerintah Desa Kauneran, serta realisasi Anggaran Pendapatan dan Belanja Desa periode tahun 2017.

\section{HASIL PENELITIAN DAN PEMBAHASAN \\ 4.1 Hasil Penelitian}

\subsubsection{Penyusunan Rencana Pembangunan Jangka Menengah Desa (RKPDes)}

Rencana Pembangunan Jangka Menengah Desa (RPJM-Desa) yang adalah suatu dokumen yang menyangkut setiap perencanaan untuk periode 6 tahun yang berisi bagian arah kebijakan dalam hal pembangunan desa, arah kebijakan keuangan desa, serta kebijakan umum, program Satuan Kerja Perangkat Daerah (SKPD), lintas SKPD, dan juga program prioritas kewilayahan yang disertai dengan rencana kerja. RPJMDes Kauneran Kecamatan Sonder Kabupaten Minahasa yang disusun setelah dilantiknya kepala desa pada bulan Agustus tahun 2016 maka pemerintah, masyarakat dan pihak yang terkait menyusun Rencana Pembangunan Jangka Menengah Desa (RPJM-Desa) tahun 2017-2022 yang menggambarkan permasalahan terkait pembangunan desa sesuai dengan kebutuhan masyarakat serta programprogram pembangunan desa di awali dari musyawarah rencana pembangunan (musrenbang) desa yang dihadiri oleh masyarakat, pemerintah desa, tokoh masyarakat, tokoh agama, tokoh pemuda, kaum perempuan serta kepala-kepala jaga bersama pelaku pemberdayaan masyarakat dalam penggalian gagasan. Merumuskan arah kebijakan dasar dan strategi pembangunan Desa Kauneran kecamatan Sonder Kabupaten Minahasa yang dapat mendorong peran aktif seluruh elemen masyarakat pada desa Kauneran di dalam kegiatan pembangunan untuk mewujudkan masyarakat yang lebih sejahtera serta mengarahkan program dan kegiatan yang dilakukan oleh seluruh elemen baik pemerintah dan masyarakat serta mewujudkan pencapaian visi dan misi desa.

\subsubsection{Penyusunan Rencana Kerja Desa (RKPDes)}

Setelah disusunnya Rencana Pembangunan Jangka Menengah Desa (RPJMDes) Kauneran Kecamatan Sonder Kabupaten Minahasa selanjutnya Pemerintah Sebagaimana yang diamanatkan dalam UU No. 6 Tahun 2014 Tentang Desa Pasal 71-75 yang menjelaskan tentang sumber pendapatan dan Belanja Desa, maka desa diwajibkan menyusun Dokumen Rencana Pembangunan Jangka Menengah Desa (RPJM-Desa) untuk jangka waktu 6 (enam) 
Tahun dan Dokumen Rencana Pembanguna Desa (RKP-Desa) sebagai satu kesatuan sistem perencanaan pembangunan Daerah/Kabupaten secara partisipatif dan transparan. RKP Desa Kauneran adalah Rencana Kerja Pemerintah Desa yang dibuat untuk jangka waktu 1 (satu) tahun yang berdasarkan penjabaran dari RPJM Desa, sebagaimana hasil evaluasi dan kesepakatan desa Kauneran serta pelaksanaan pembangunan tahun sebelumnya, prioritas kebijakan desa dan hal - hal yang karena keadaan darurat / bencana alam. Sebagai Rencana Strategis pembangunan tahunan pada desa Kauneran, Renacana Kerja Pemerintah Desa merupakan dokumen perencanaan pembangunan yang bersifat regular yang pelaksanaannya dilakukan oleh Lembaga Ketahan Masyarakat Desa sebagai lembaga yang bertanggung jawab di desa. Rencana Kerja Pemerintah Desa Kauneran merupakan pedoman atau acuan pelaksanaan pembangunan bagi Pemerintah Desa dalam jangka waktu satu tahun yang selanjutnya dimasukkan dalam APB Desa tahun anggaran 2017.

\subsubsection{Anggaran Pendapatan dan Belanja Desa (APBDes)}

Dalam pengelolaan keuangan desa Kauneran sesuai peraturan perundangan yang berlaku, salah satu diantaranya Peraturan Menteri Dalam Negeri Nomor 113 Tahun 2014 tentang Pengelolaan Keuangan Desa, dan mencerminkan keberpihakan terhadap kebutuhan riil setiap tahunnya pemerintah desa Kauneran bersama Badan Permusyawaratan Desa menetapkan Peraturan Desa tentang Anggaran Pendapatan dan Belanja Desa (APBDes) secara partisipatif dan transparan yang proses penyusunannya dimulai dengan lokakarya pada desa Kauneran, konsultasi publik dan rapat umum Badan Permusyawaratan Desa untuk penetapannya.Pendapatan Desa Kauneran meliputi semua penerimaan uang melalui rekening desa yang merupakan hak desa dalam 1 (satu) tahun anggaran yang tidak perlu dibayar kembali oleh desa. Belanja pada desa meliputi semua hal pengeluaran diambil dari rekening desa adalah kewajiban pihak desa terkait dalam jangka waktu 1 (satu) tahun anggaran yang tidak akan diperoleh pembayarannya kembali oleh desa. Pendapatan Desa terdiri atas kelompok:

1. Pendapatan Asli Desa (PADesa);

2. Transfer; dan

3. Pendapatan Lain-Lain.

Pada peendapatan Asli Desa meliputi :

1. Hasil usaha;

2. Hasil aset;

3. Swadaya, partisipasi dan Gotong royong; dan

4. Lain-lain pendapatan asli desa.

Belanja desa dipergunakan dalam rangka mendanai pembangunan serta penyelenggaraan kewenangan Desa yang dibutuhkan terdiri dari program-program kegiatan yang telah disusun dalam APB-Desa. Klasifikasi Belanja Desa terdiri atas kelompok:

1. Penyelenggaraan Pemerintahan Desa;

2. Pelaksanaan Pembangunan Desa;

3. Pembinaan Kemasyarakatan Desa;

4. Pemberdayaan Masyarakat Desa; dan

5. Belanja Tak Terduga.

Bagian dari kelompok belanja terbagi dalam kegiatan-kegiatan sesuai dengan kebutuhan dari pihak Desa Kauneran yang telah dituangkan dalam dokumen RKP-Desa. Kegiatan terdiri atas jenis belanja :

1. Pegawai;

2. Barang dan Jasa; dan

3. Modal.

Jenis belanja pada pegawai, dianggarkan untuk pengeluaran pada penghasilan tetap dan tunjangan bagi pihak Kepala Desa dan Perangkat Desa Kauneran serta tunjangan BPD. 
Belanja pegawai pelaksanaannya dibayarkan pada setiap bulan. Belanja barang dan jasa yang gunakan untuk pengeluaran pembelian atau dengan pengadaan barang yang nilai manfaatnya kurang dari 12 bulan. Belanja barang dan jasa yang termasuk didalamnya adalah.

1. Alat tulis kantor;

2. $\mathrm{NHGH}$

3. Benda pos;

4. Bahan/material;

5. Pemeliharaan;

6. Cetak/penggandaan;

7. Sewa kantor desa;

8. Sewa perlengkapan dan peralatan kantor;

9. Makanan dan minuman rapat;

10. Pakaian dinas dan atributnya;

11. Perjalanan dinas;

12. Upah kerja;

13. Honorarium narasumber/ahli;

14. Operasional Pemerintah Desa;

15. Operasional BPD;

Tabel 4.1 Total Anggaran Pendapatan dan Belanja Desa (APBDes) Kauneran Tahun 2017

\begin{tabular}{|c|c|c|c|c|}
\hline URAIAN & $\begin{array}{c}\text { TOTAL } \\
\text { ANGGARAN }\end{array}$ & \multicolumn{2}{c|}{$\begin{array}{c}\text { TOTAL } \\
\text { REALISASI }\end{array}$} & LEBIH/KURANG \\
\hline $\begin{array}{c}\text { Total Anggaran dan } \\
\text { Realisasi Pendapatan }\end{array}$ & Rp. 1.081.988.500,- & Rp. $1.081 .179 .000,-$ & Rp. 809.500,- \\
\hline $\begin{array}{c}\text { Total Anggaran dan } \\
\text { Realisasi Belanja }\end{array}$ & Rp. 1.081.988.500,- & Rp. $1.081 .179 .000,-$ & Rp. 5.809.500,- \\
\hline
\end{tabular}

\subsection{Pembahasan}

4.2.1 Penyusunan Rencana Pembangunan Jangka Menengah Desa (RPJMDes)

Dilihat dari prespektif waktunya, perencanaan anggaran di tingkat pemerintah desa yang didalamnya terdapat Rencana Pembangunan Jangka Menengah Desa (RPJMDes) merupakan perencanaan pemerintah desa untuk periode 6 tahun dan Rencana Kerja Pemerintah Desa (RKPDes) merupakan rencana tahunan pemerintah desa yang diadakan setahun sekali. Adapun Rencana Pembangunan Jangka Menengah adalah dokumen perencanaan pemerintah desa Kauneran yang memuat penjabaran dari visi dan misi pemeritah desa dan program-program desa sehingga dalam penyusunan Rencana Pembangunan Jangkah Menengah Desa memuat perencanaan pembangunan selama 6 tahun.

Dalam penyusunan RPJMDes pemerintah sesuai dengan Pemendagri No.114 Tahun 2014 bahwa penyusunan RPJMDes 3 Bulan setelah dilantiknya Kepala Desa yang terpilih pada bulan Juli tahun 2016 dan dilantik dilaksanakan pada bulan Agustus maka desa Kauneran sesuai dengan waktu yang ditetapkan oleh pemerintah. Secara administrative pemerintah desa terbagi dalam empat wilayah jaga. Setiap pelaksanaan pembangunan di Desa Kauneran dilakukan lewat musyawarah pembangunan dengan mempertimbangkan dampak dari pembangunan tersebut dapat memberikan nilai positif bagi selurah masyarakat. Setiap rencana pembangunan di desa baik pembangunan yang didanai oleh pemerintah lewat APBD, APBN, atau dari pihak lain diumumkan secara transparan di masyarakat dengan mengikuti pola dan mekanisme yang ditetapkan. Pelaksanaan program-program pemerintah yang bersifat pembangunan infrastrutur desa dan sarana prasarana dasar selalu melibatkan partisipasi swadaya masyarakat. Hal ini untuk membangun rasa kebersamaan dan rasa 
memiliki untuk terus menjaga dan merawat fasilitas yang ada. Selain melaksanakan pola pembangunan yang terencana, pemerintah desa Kauneran juga mengambil keputusan sebagai kebijakan pelaksanaan pembangunan berdasarkan kondisi penting dan mendesak tetapi tidak bertentangan dengan pola aturan atau mekanisme program pembangunan yang berlaku. Proses merencanakan, melaksanakan, dan mengevaluasi sendiri dalam kegiatan pembangunan desa Kauneran adalah wujud nyata dari kewenangan mengatur dan mengurus pembangunan desa yang berskala lokal desa sehingga dalam konteks desa membangun berdasarkan asas kewenangan lokal berskala desa maka program pembangunan desa Kauneran memfokuskan pada pembangunan yang berkepentingan yang menjadi hasil musyawarah bersama masyarakat terdiri dari:

1. Pekerjaan Bak Air Tipe 1

2. Pekerjaan Bak Air Tipe 2

3. Penerangan Jalan umum tenaga Surya

4. Pekerjaan Pemeliharaan penerangan Jalan Umum Tenaga Surya

5. Pekerjaan Pipa Air Bersih

6. Betonisasi Jalan

7. Pekerjaan Talud Pasang Batu

8. Pekerjaan Jalan lapis Sirtu

\subsubsection{Penyusunan Rencana Kerja Pemerintah Desa (RKPDes)}

Penyusunan Rencana Kerja Pemerintah Desa (RKPDes) dalam jangka waktu satu tahun merupakan rencana strategis pembangunan tahunan desa yang adalah penjabaran dari Rencana Pembangunan Jangkah Menengah Desa (RPJMDes) yang menggambarkan strategis arah prioritas kebijakan desa berkaitan dengan prioritas program dan kegiatan serta pendanaannya yang ditetapkan dengan Rancangan Peraturan Desa (RAPERDes) yang telah dibuat. Tahapan jadwal penyusunan RKPDes sesuai Pemendagri No. 114 Tahun 2014 pada bulan Juni tahun berjalan disesuaikan setelah penyusunan RPJMDes sehingga waktu penyusunan tidak lewat sesuai dengan peraturan yang ditetapkan. Seperti halnya dalam penyusunan RPJMDes, RKPDes disusun oleh pemerintah dan masyarakat dalam musyawarah rencana pembangunan desa sehingga melalui musrenbang dari himpunan masyarakat semua usulan dari masyarakat apa yang penting sehingga berkaitan dengan visi dan misi desa. Peran pemerintah dalam musrenbang yang kemudian dibahas oleh Badan Permusyawaratan Desa (BPD) dan setelah itu di sampaikan kepada pemerintah kecamatan setelah disetujui ditetapkan peraturan desa. Sehingga berkaitan dengan program yang ada untuk menetapkan kegiatan dan kebutuhan pembangunan desa Kauneran yang diperlukan yang di danai oleh Anggaran Pendapatan dan Belanja Desa, swadaya masyarakat desa dan/atau Anggaran Pendapatan dan Belanja Daerah (APBD).

Program-program yang telah disusun oleh pemerintah desa Kauneran yang tercantum dalam hasil penelitian pada Anggaran Pendapatan dan Belanja Desa yang telah dilampirkan dilihat berdasarkan penilaian terhadap :

1. Peningkatan kapasitas penyelenggaraan pemerintahan Desa

2. Peningkatan kualitas dan akses terhadap pelayanan dasar

3. Pembangunan dan pemeliharaan infrastruktur dan lingkungan berdasarkan kemampuan teknis dan sumber daya lokal yang tersedia

4. Pengembangan ekonomi pertanian berskala produktif

5. Pemanfaatan teknologi tepat guna untuk kemajuan ekonomi;

6. Pendayagunaan sumber daya alam

7. Pelestarian adat istiadat dan sosial budaya Desa

8. Peningkatan kualitas dalam ketertiban dan ketenteraman bagi masyarakat Desa berdasarkan prioritas dan kebutuhan masyarakat Desa 
9. Peningkatan kapasitas masyarakat dan lembaga kemasyarakatan Desa.

Dalam program yang dibahas pemerintah desa Kauneran juga berkoordinasi dengan pemerintah Kabupaten yang mempunyai kewenangan terkait dengan penyusunan. Hasil kesepakatan musyawarah perencanaan pembangunan ditetapkan dengan Peraturan Desa (Perdes) No. 01 Tahun 2017 tentang Rencana Kerja Pemerintah Desa (RKPDes) Kauneran yang telah ditetapkan dan akan diusulkan pada pemerintah daerah Kabupaten melalui mekanisme perencanaan pembangunan desa dan juga sebagai dasar dalam penyusunan perubahan Anggaran Pendapatan dan Belanja Desa (APBDes).

\subsubsection{Anggaran Pendapatan dan Belanja Desa (APBDes)}

Sebagaimana hasil musyawarah rencana pembangunan pemerintah desa Kauneran bersama dengan masyarakat atas program Rencana Kerja Pemerintah Desa (RKPDes) yang merupakan program pemerintah desa dalam jangkah waktu satu tahun sesuai dengan Rancangan Peraturan Desa (RAPERDes). Hasil musyawarah inilah ditetapkannya menjadi APBDes dan selanjutnya diajukan kepada Bupati melalui Camat guna untuk mengevaluasi dan mendapat persetujuan dari setiap program yang telah disusun. Setelah dievaluasi oleh pemerintah Kabupaten, maka Kepala Desa bersama BPD melakukan penyesuaian RAPERDes tentang APBDes sesuai dengan hasil evaluasi dan selanjutnya ditetapkan oleh pemerintah desa menjadi Peraturan Desa (Perdes). Setelah itu Peraturan Desa yang telah ditetapkan desa dikirim kepada Bupati.

Didalam Perdes APBDes tertuang dokumen pelaksanaan anggaran dan Perdes APBDes yang telah ditetapkan kemudian disosialisasikan dan kemudian dilaksanakan oleh pemerintah desa Kauneran. Setelah itu Kepala Desa melakukan pertanggung jawaban atas terlaksananya Anggaran Belanja dan Pendapatan Desa (APBDes) Kauneran. Prioritas dalam kebijakan pada program pembangunan Desa Kauneran yang telah tersusun dalam RKP Desa Tahun 2017 sepenuhnya didasarkan pada berbagai kepentingan dan keseahteraanmasyarakat. Sehingga prioritas program pembangunan yang disusun pada tahun 2017 yang telah dilaksanakan dapat menaggulangi permasalahan dimasyarakat, terutama upaya meningkatkan keberpihakan pembangunan terhadap hak-hak dasar masyarakat, seperti kesehatan dan pendidikan. Dengan demikian arah dan kebijakan pembangunan desa secara langsung dapat berperan aktif menanggulangi kemiskinan pada level desa yang sesuai dengan Pemendagri No.113 Tahun 2014 Tentang Pengelolaan Keuangan Desa.

\section{KESIMPULAN DAN SARAN \\ 5.1 Kesimpulan}

Berdasarkan hasil penelitian dan pembahasan tentang proses penyusunan anggaran pada desa Kauneran Kecamatan Sonder Kabupaten Minahasa dapat ditarik kesimpulan, yaitu.

1. Penyusunan Rencana Program Jangkah Menengah Desa (RPJM-Desa) tahun 2017-2022 dalam tahap awal waktu penyusunan 3 bulan setelah dilantiknya Kepala Desa pada bulan Agustus dan terelisasi pada bulan November telah sesuai dengan Pemendagri 114 Tahun 2014 Pasal 5 ayat 2 dan juga dalam penyusunan RPJMDes diadakan musyawarah rencana pembangunan desa bersama aparat pemerintah desa masyarakat dan BPD sehingga tersusun program-program jangkah menengah selama 6 tahun sehingga peran masyarakat menjadi kualitas program-program dalam pembangunan yang dibutuhkan dan juga menjadi pedoman dalam penyusunan RKPDes selanjutnya pada desa Kauneran Kecamatan Sonder Kabupaten Minahasa. Penyusunan Rencana Kerja Pemerintah Desa (RKP-Desa) tahun 2017 yang telah di musyawarahkan oleh pemeritah dan masyarakat yang sesuai dengan informasi pemerintah daerah untuk pembangunan yang juga terdapat Peraturan Desa (Perdes) didalamnya rencana kerja yang telah berjalan sesuai dengan Perdes sehingga Rencana Kerja Pemerintah Desa Kauneran menjadi acuan APBDes tahun 2017 dan telah disetujui oleh pemerintah Kabupaten. 
2. Anggaran Pendapatan dan Belanja Belanja Desa Kauneran sebaimana telah tercantum pada hasil penelitian dan pembahasan program-program baik pembangunan dan kesejahteraan masyarakat sudah tercantum sesuai dengan Pemendagri 114 Tahun 2014 karena sudah dievaluasi dan di teliti oleh pemerintah daerah sehingga dana APBDes sudah digunakan sebagaimana dalam Laporan Realisasi Anggaran Pendapatan dan Belanja Desa dan masih ada program yang belum terelasisasi bukan hanya didesa Kauneran melainkan desa yang ada di Kabupaten Minahasa.

\subsection{Saran}

Proses musyawarah rencana pembangunan desa Kauneran bukan hanya sudah sesuai jadwal yang ditetapkan pemerintah tetapi kualitas murenbang yang telah diselenggarakan didalamnya pembahasan mengenai program pembangunan dan kebutuhan masyarakat juga dalam tahapan penyelenggaraan program sampai pada Anggaran Pendapatan dan Belanja Desa dipertahankan juga semakin diupayakan agar tahap penyusunan anggaran pembangunan dan kesejahteraan masyarakat desa Kauneran pada tahun berikutnya lebih baik dan peran pemerintah dan masyarakat semakin dipererat untuk kesejahteraan bersama.

\section{DAFTAR PUSTAKA}

Abdul, Halim. 2014. Akuntansi Sektor Publik: Akuntansi Keuangan Daerah. Edisi Empat. Salemba 4. Jakarta.

Aida, F. 2013. Perencanaan dan Penganggaran Pemerintah Daerah Otonomi Khusus Ditinjau Pere Dari Aspek Keperilakuan. Jurnal Akuntansi Multiparadigma. Vol.1 No.1. Universitas Syiah Kuala. Aceh

Anthony, Robert. N, dan Vijay, Govindarajan. 2013. Sistem Pengendalian Manajemen. Edisi 12. Buku 2. Karisma Publishing Group. Jakarta.

Bastian, Indra. 2013. Akuntansi Sektor Publik. Edisi Ketiga. Erlangga. Jakarta.

Bastian, Indra. 2014. Sistem Pengendalian Manajemen Sektor Publik. Salemba Empat. Jakarta.

Creswell, John. W. 2012. Research Design : Qualitative, Quantitative and Mixed Methods Approaches. Sage Publication Inc. Califomia

Effendi, R. 2015. Accounting Principles: Prinsip-Prinsip Akuntansi Berbasis SAK ETAP. Rajagrafindo Persada. Jakarta.

Harahap, S. 2015. Teori Akuntansi. Rajawali Pers. Jakarta.

Pangalila, C. 2017. Evaluasi Penyusunan Anggaran dan Kinerja Keuangan di Kecamatan Sonder Kabupaten Minahasa. Jurnal Riset Akuntansi 12(2), 661-670. Universitas Sam Ratulangi. Manado

Peraturan Menteri Dalam Negeri Republik Indonesia Nomor 113 Tahun 2014 Tentang Pedoman Pengelolaan Keuangan Desa.

Peraturan Menteri Dalam Negeri Republik Indonesia Nomor Nomor 114 Tahun 2014 Tentang Pedoman Pembangunan Desa.

Peraturan Pemerintah Republik Indonesia Nomor 47 Tahun 2015 Tentang Peraturan Pelaksanaan Undang-Undang Republik Indonesia Nomor 6 Tahun 2014 Tentang Desa.

Sasongko, Catur dan Safrida Rumondang Parulian. 2013. Anggaran. Salemba Empat. Jakarta. Sugiyono. 2014. Metode Penelitian Kuantitatif dan Kualitatif $(R \& D)$. Alfabeta CV. Bandung Undang-Undang No. 9 Tahun 2015 Tentang Pemerintahan Daerah.

Wiratna, S. 2015. Akuntansi Sektor Publik. Penerbit Pustaka Baru Press. Yogyakarta. 